\title{
THE APPLICATION OF ISLAMIC VALUE AND REGIONALISM IN THE REDESIGN OF ZAINUL HASAN GENGGONG BOARDING SCHOOL IN PROBOLINGGO INDONESIA
}

\author{
Nur Rozan Jurusan Teknik Arsitektur \\ Universitas Islam Negeri Maulana Malik Ibrahim \\ Malang, Indonesia \\ e-mail: Lucha_luis@yahoo.com \\ Ernaning Setiyowati \\ Jurusan Teknik Arsitektur \\ Universitas Islam Negeri Maulana Malik Ibrahim \\ Malang, Indonesia \\ e-mail: ninkarch99@yahoo.com \\ Pudji Pratitis Wismantara \\ Jurusan Teknik Arsitektur \\ Universitas Islam Negeri Maulana Malik Ibrahim \\ Malang, Indonesia
}

\begin{abstract}
Zainul Hasan Genggong boarding school is an islamic and public school. The school has been existed from many years ago in a lack design. The amount of the room also need to be added. That is why the redesign of this building should be done. The redesign of the school have an objective to improve and develop the education quality. The design theme used in the new design is reinvigorating tradition from Pendhalungan culture. There are some islamic values in Pendhalungan culture and tradition, i.e. Ma'iyyah (togetherness) concept, modest concept, and not excessive concept. The three islamic concept together with the Pendhalungan culture atmosphere are showed into the whole aspect of the new design, including site, room, and the building form.
\end{abstract}

Keywords: boarding school, Pendhalungan, reinvigorating tradition

\begin{abstract}
Abstrak
Pondok pesantren Zainul Hasan Genggong merupakan pendidikan islam yang juga mengajarkan pendidikan umum. Pondok pesantren ini sudah berdiri sejak beberapa tahun yang lalu dengan masih banyak kekurangan desain. Jumlah kamar juga masih perlu ditambah. Karena itulah diperlukan perancangan kembali bangunan ini. perancangan kembali memiliki tujuan untuk meningkatkan dan mengembangkan kualitas pendidikan. Tema rancangan yang digunakan untuk desain yang baru ini adalah reinvigorating tradition dari budaya Pendhalungan. Di dalam budaya Pendhalungan terdapat nilai-nilai islam, antara lain konsep Ma'iyyah (kebersamaan), konsep kesederhanaan, dan konsep tidak berlebih-lebihan. Ketiga konsep islam tersebut bersama dengan suasana Pendhalungan ditunjukkan ke dalam seluruh aspek perancangan baru, termasuk ke dalam desain tapak, ruang, dan bentuk bangunan.
\end{abstract}

Kata kunci: pondok pesantren, Pendhalungan, reinvigorating tradition

\section{Introduction}

Zainul Hasan Genggong Boarding School in Proboliggo Indonesia is an Islamic boarding school that has been established since 1839. It is one of the oldest boarding school in Indonesia. During the times, the school experienced a good progress that is shown in the amount of the student (santri) that now reach 3000 santri, 1300 male and 1700 female ${ }^{1}$. Unfortunately the quantity of the santri is not conformable with the quality of the school building. Therefore it needs to be redesigned to excogitate a better quality of boarding school.
The enhancement of the amount of santri in the shcool leads the lack of the accomodate facilities, such as room, green areas, parking lot, etc. Another problems emerged is the availability of the clean water for the daily needs ${ }^{2}$. Those problems will be resolved by the redesign of the school.

The design of the existing building is used a modern architectural style without thinking about some meaning of the architecture and the islamic values. The new design will observe some problems of the school bulding and put a spesific theme to create a meaningful architecture. 
The design theme that will be used is reinvigorating tradition to create an architecture that is suitable with the culture and regional architecture. It is the theme that attempt to represent something that had ever existed, in the new form with the characteristic to accentuate a new traditional atmosphere and understand the essence of shape arrangement. The form and the material could not be the same but it will maintain the regional architecture's identity.

Probolinggo is a region that has been known with Pendhalungan culture. This culture is formed by two different cultures in Indonesia that is Java and Madura $^{3}$. But it does not seem to be implemented by the people living in the region, so it needs to be represented in the form of a new building of Zainul Hasan Genggong boarding school. It has a purpose to acquaint the culture to the people so they can remember, develop, and conserve the culture so it will not be vanished by the time. It hopes that the traditional value will keep maintained through the building in the reinvigorating tradition theme.

It is apropriate with al-Qur'an Surah Ibrahim 4 which said that "And We did not send any apostle but with the language of his people, so that he might explain to them clearly; then Allah makes whom He pleases err and He guides whom He pleases and $\mathrm{He}$ is the Mighty, the Wise" (QS. Ibrahim:4).

It explains that an apostle preaches with the local language and local tradition so the meaning could be transfered easily to the people. It shows that culture or local tradition could be a good media to learn something new so it can be easily accepted by the local communities.

\section{Reinvigorating Tradition as An Architecture Design Theme}

Reinvigorating tradition is one of the subtheme of a big theme called 'regionalism'. Regionalism in architecture is an architectural form that accentuate value of local tradition that is adopted by the local people. This theme has some principles to present the old form to the new one (reinvigoration old tradition).

According to William Lim, William S.W, and Tan Hock Beng ${ }^{4}$, the characteristics of reinvigorating tradition theme are:

1. Accentuate the present of traditional atmosphere into something new

2. Understand the essence of traditional form arrangement

3. The form and material could be different from the old material used in the old traditional building

some things that influence the reinvigorating tradition theme are culture, people, economic, geography, and also climate. In this matter, the redesign of Zainul Hasan Genggong boarding school is focused on culture and local tradition called Pendhalungan culture that is start to eroded during the times. It is also bring back the culture and the atmosphere of boarding school, and do not leave the santri culture as a muslim district.

Probolinggo is a region that the people living in it comes from two different regions, i.e. Java and Madura. It shows from the local language used by the local people. The region also has many of boarding shools, and one of them and the oldest one is Zainul Hasan Genggong ${ }^{5}$.

\section{The Islamic Value of the Redesign of the Boarding School}

One of the Qur'an verses that explains about something related to reinvigorating is Surah atTakatsur 1-8 which says that Allah forbid His people to live the excessive life. This is apropriate with the theme that present the traditional atmosphere into the new form, which is known that the traditional form is not luxurious.

Abundance diverts you [1], Until you come to the graves [2], Nay! You shall soon know [3], Nay! Nay! You shall soon know [4], Nay! If you had known with a certain knowledge [5], You should most certainly have seen the hell [6], Then you shall the most certainly see it with the eye of certainty [7], Then on that day you shall most certainly be questioned about the boons [8]. (QS. At-Takatsur 1-8).

The values contained in the verse $a^{6}{ }^{6}$ :

1. Modesty

Modesty here means that the design uses the material that is harmonious with the environment, and also provide the building fasade impression to be not excessive. Those material's choice will compose the modesty atmosphere in the design.

2. Not excessive

Not excessive here is also implemented in the materials. The material used in this design is local materials, and has been calculated before so there will not be wasted material. the design also apropriate with the function and do not waste some form that is not useable as a room.

\footnotetext{
The Redesign of Zainul Hasan Genggong Boarding School

The design concept of the region of the boarding school uses Ma'iyyah concept (togetherness), in the meaning of diverse and unity between one building and the others. Meanwhile, the concept of the building uses reinvigorating tradition from Pendhalungan house mixed with local culture characteristic. The existing site of the boarding school is shown in Figure 1.
} 


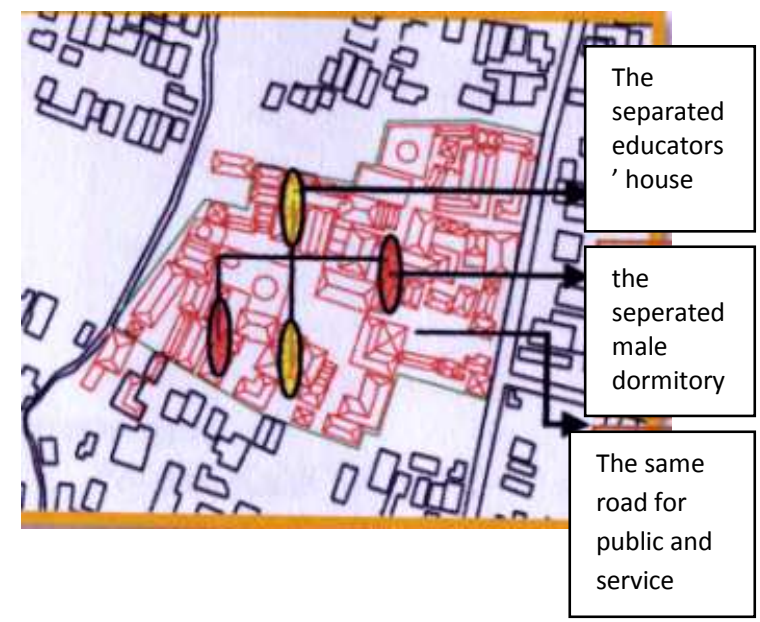

Figure 1. The Existing Site of Zainul Hasan Genggong Boarding School (Source: Survey, 2012)

The existing site of the boarding school shows the unarranged of the building zone. The house of the educators are separated in the north and the south of the site. The male rooms are also separated in the west and east of the site. The pathway for public and service is not separated. Some of the design failure makes this building is not used properly. Those design failure will be fixed in the redesign. It is shown in Figure 2.

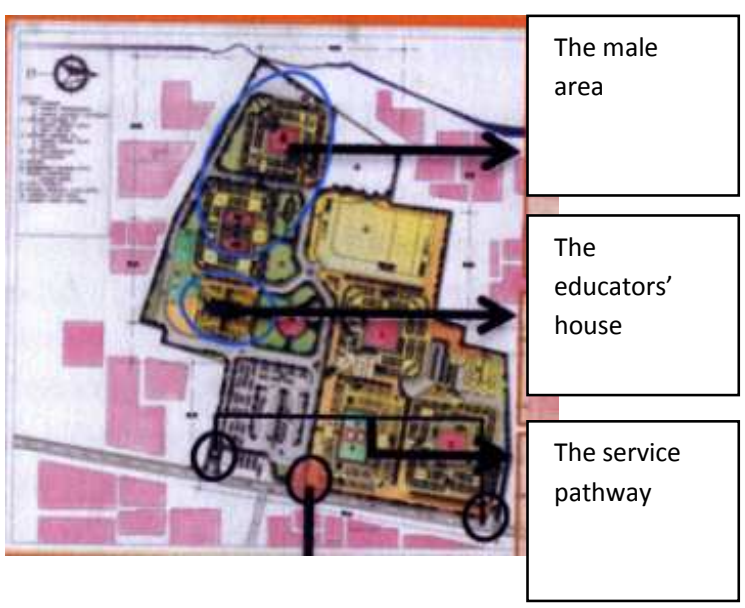

Figure 1. The Site Plan of the Redesign of the Boarding School (Source: Design, 2012)

The new design connects some seperated building in the same function. The male room that was separated before, is collected in the same zone which is the north area of the site. The amount of the room is also added to enhance the number of the santri. The educator house is also united to the same zone. The pathway is separated into some ways, divided by the function; public, service, to the male area, and to the female area.

\section{The Building Layout}

The application of the islamic principles and reinvigorating tradition are shown in the building layout, room arrangement, and site circulation. The islamic principle shown in the building layout is ma'iyyah that means unity. It is shown in Figure 3

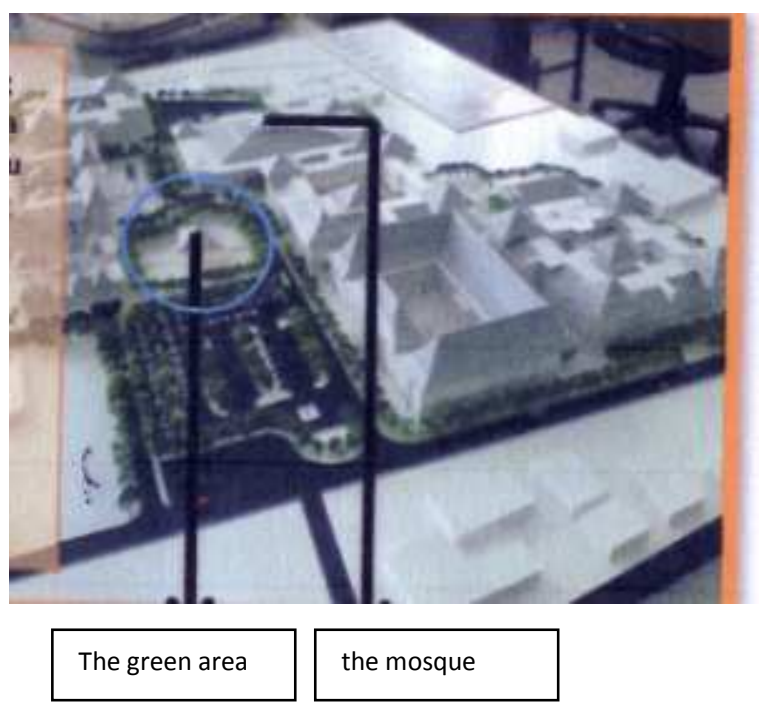

Figure 3. The Site Plan of the Redesign of the Boarding School (Source: Design, 2012)

The form that create a harmony between one building and another makes this site have a unity. It is shown that the design interprates the ma'iyyah concept that suits with the common life of boarding school that maintain solidarity, modesty, and togetherness. So that the character of the site is appropriate with the islamic principle as a point of Rahman lil 'Alamin.

\section{The Circulation}

One of the important things in design is site and room circulation. The circulation of the redesign of the boarding school consists of three parts; i.e. visitor lane circulation by vehicles, pedestrian ways, and service lane circulation. The service lane circulation is devided into two parts; i.e. the access to the male building and to the female one. The division aims to provide an easiness for building users.

Meanwhile the vehicle circulation uses the linier style of circulation and is directly headed to the parking lot. The pedestrian ways are also linier like the vehicle's yet different elevation. The site circulation is shown in Figure 4. 


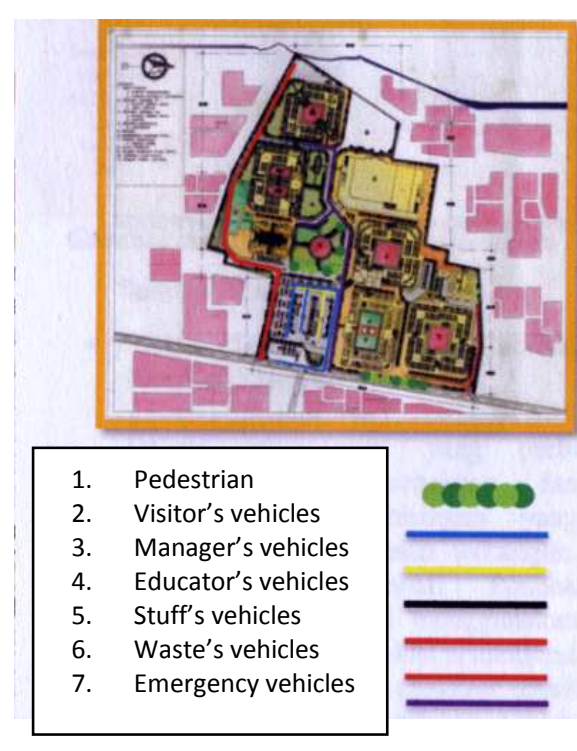

Figure 4. The Site Circulation (Source: Design, 2012)

The linier style of site circulation is an application of the circulation in Pendhalungan House. It is to facilitate the user and not to disturb the activities on the site. Whereas the circulation inside the buildings also an application from the circulation of Pendhalungan House. It is shown in Figure 5 and 6.

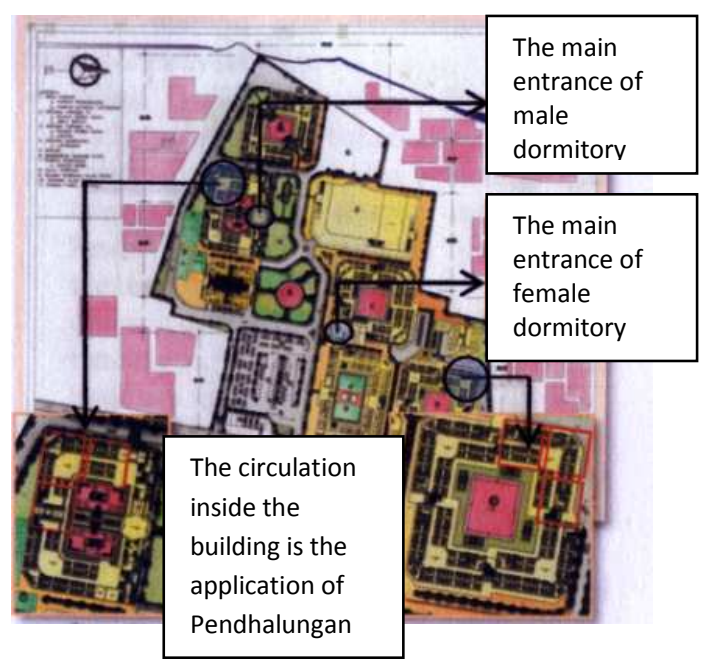

Figure 5. The Circulation Inside the Buildings (Source: Design, 2012)

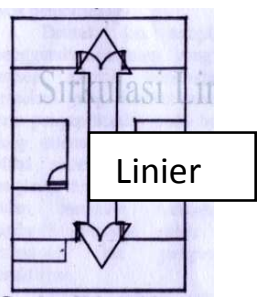

Figure 6. The Room Circulation in Pendhalungan House (Source: Design, 2012)

\section{The Room}

The room in the redesign of the boarding school applies the concept of Pendhalungan House. It consists of three aspect; i.e. amper, roma, and dapor. The room arrangement distinguish private and public room to provide the environment that is appropriate with the concept of Rahmatan lil 'Alamin. Those are interpreted in the building plan as shown in Figure 7.

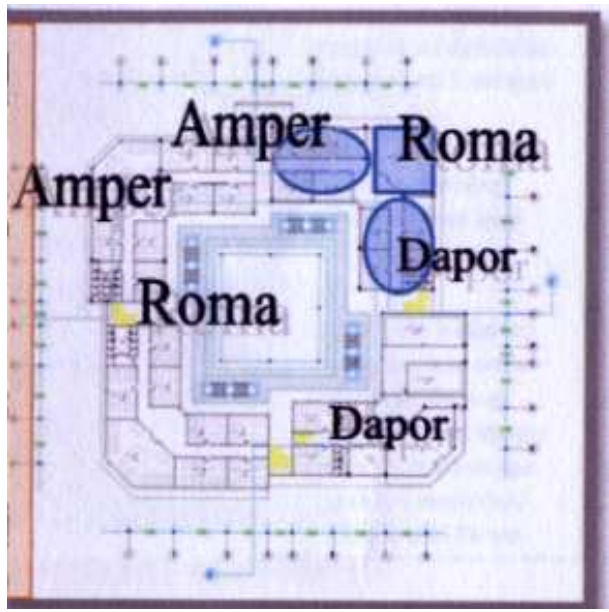

Figure 7. The Room Specification of Building Plan (Source: Design, 2012)

\section{The Environment Architectural Design}

Air movements, lighting, and noise control are needed to be noticed in the architectural design. An adequate ventilation is given to provide air movement in each room in order to anticipate the humidity inside the room. The use of water glass in the stair area is given to provide natural light inside the room. The use of shading device is given as a sunlighting filter. It is shown in Figure 8.

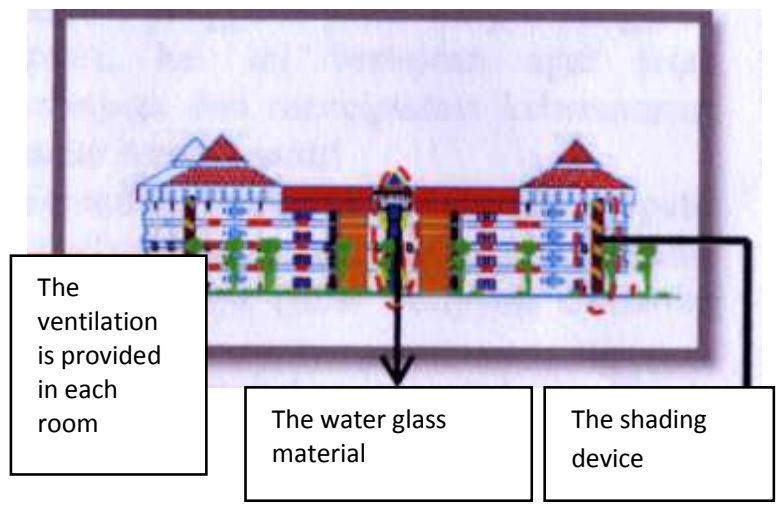

Figure 8. The Building Facade (Source: Design, 2012)

\section{The Building Form and View}

The value contained in at-Takatsur that is applied in the design aspects is the prohibition to 
live pretentiously. So there are modesty and not excessive value in living a life. The modesty value is applied in the use of building material that is harmonious with the environment. The not excessive value is also applied in the way of using the building material.

The form and view of the building use the concept of Pendhalungan house that is symmetrical and appropriate with the environment. It is shown in the building roof that uses the joglo style. Figure 9 and 10 show that the redesign of the building is appropriate with the buildings around the site.

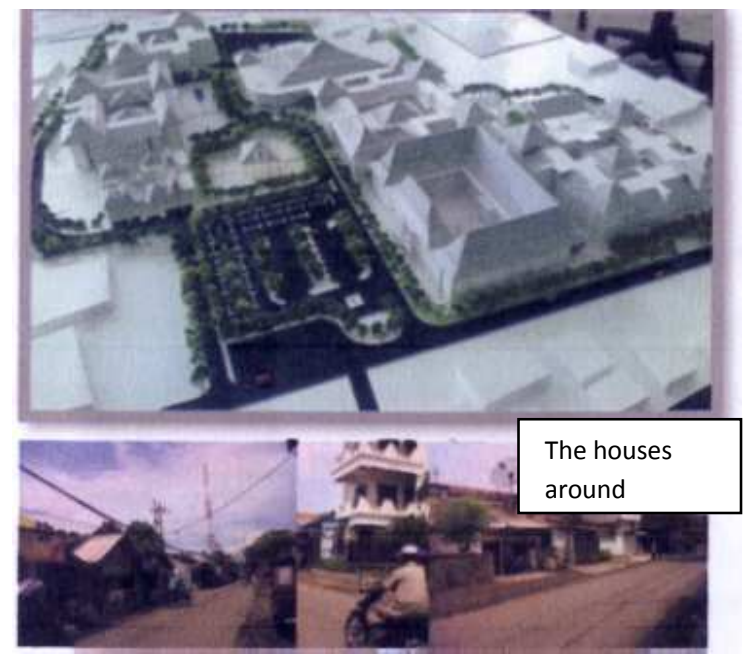

Figure 9. The New Design of the Boarding School Compares to the Buildings Around (Source: Design, 2012)

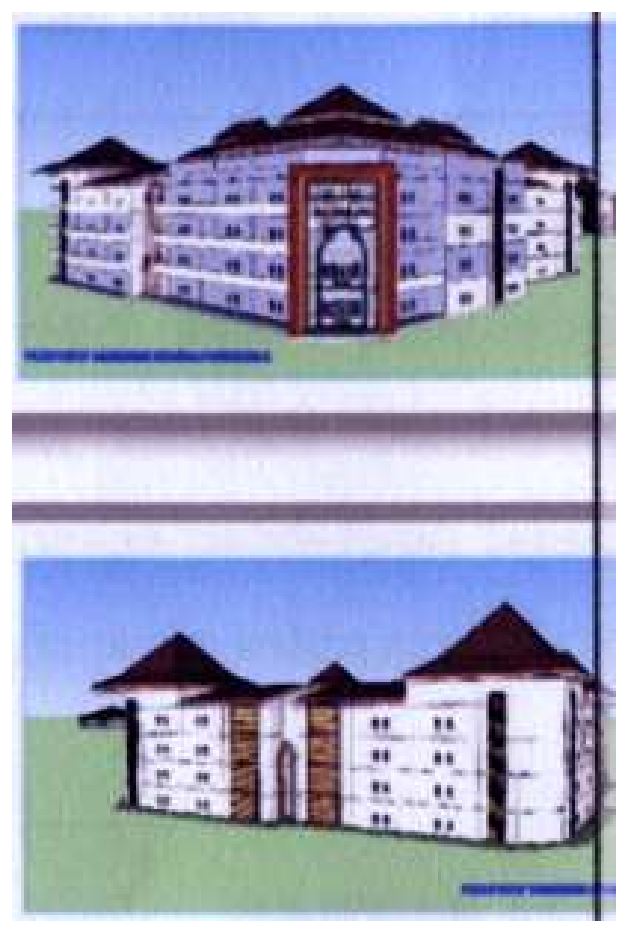

Figure 10. The View of the Building Uses Joglo Style Roof (Source: Design, 2012)

\section{Conclusion}

The use of some Islamic values and a spesific theme in an architectural design will lead an architecture to have a meaningful design. Just like the redesign of Zainul Hasan Genggong Boarding Scholl that had no meaning in the old design. The new design of the boarding school notices the needs of the user and also the aesthetic factor. Some building with the same function that was seperated before is collected in the same zone of the site. The look of the design is changed to create the unity of design. The touch of the Pendhalungan architecture is used to put some meaning in the building. It applied in the arrangement of the building zone, the circulation, and also the building fasade. So the users will feel the atmosphere of locality. Moreover the islamic values are added in the look of the building to picture the modesty of moslem's life that is represented by the santri(s).

\section{Reference}

1 Aziz Wahab, Abdul \& Haris, Wafi. 2007. Profil Pesantren Zainul Hasan Genggong Probolinggo.

Abdul Aziz. 2011. Filsafat Pesantren Genggong Probolinggo ArchiBudayaPendhalungan.html

http://Arsitektur_Desain Tan Hock Beng. 1998. Contemporary Vernacular. Singapore: Select Book Pte Ltd.

5 http://karaktersosial-probolinggo.html

6 Abdul Munir Mulkhan. 2010. Nilai-Nilai Islam dalam Tembang Jawa. Kasus Kitab Bayan Budiman. Banjarmasin 